Article

\title{
Antimicrobial and Antioxidant Polyketides from a Deep-Sea-Derived Fungus Aspergillus versicolor SH0105
}

\author{
Lu-Jia Yang ${ }^{1,2}$, Xiao-Yue Peng ${ }^{1,2}$, Ya-Hui Zhang ${ }^{1,2}$, Zhi-Qing Liu ${ }^{1,2}{ }^{\oplus}$, Xin $\mathrm{Li}^{1,2}$, \\ Yu-Cheng Gu ${ }^{3}{ }^{-}$, Chang-Lun Shao ${ }^{1,2}$, Zhuang Han ${ }^{4, *}$ and Chang-Yun Wang ${ }^{1,2, *}$
}

1 Key Laboratory of Marine Drugs, The Ministry of Education of China, School of Medicine and Pharmacy, Institute of Evolution \& Marine Biodiversity, Ocean University of China, Qingdao 266003, China; yanglujia@stu.ouc.edu.cn (L.-J.Y.); pengxiaoyue@stu.ouc.edu.cn (X.-Y.P.); zhangyahui@stu.ouc.edu.cn (Y.-H.Z.); liuzhiqing@ouc.edu.cn (Z.-Q.L.); lixin8962@ouc.edu.cn (X.L.); shaochanglun@ouc.edu.cn (C.-L.S.)

2 Laboratory for Marine Drugs and Bioproducts, Qingdao National Laboratory for Marine Science and Technology, Qingdao 266237, China

3 Jealott's Hill International Research Centre, Syngenta, Bracknell, Berkshire RG42 6EY, UK; yucheng.gu@syngenta.com

4 Institute of Deep-sea Science and Engineering, Chinese Academy of Science, Sanya 572000, China

* Correspondence: zhuanghan@idsse.ac.cn (Z.H.); changyun@ouc.edu.cn (C.-Y.W.); Tel.: +86-0898-88215868 (Z.H.); +86-0532-8203-1536 (C.-Y.W.)

Received: 9 November 2020; Accepted: 9 December 2020; Published: 11 December 2020

\begin{abstract}
Fifteen polyketides, including four new compounds, isoversiol F (1), decumbenone D (2), palitantin B (7), and 1,3-di-O-methyl-norsolorinic acid (8), along with 11 known compounds (3-6 and 9-15), were isolated from the deep-sea-derived fungus Aspergillus versicolor $\mathrm{SH} 0105$. Their structures and absolute configurations were determined by comprehensive spectroscopic data, including 1D and 2D NMR, HRESIMS, and ECD calculations, and it is the first time to determine the absolute configuration of known decumbenone A (6). All of these compounds were evaluated for their antimicrobial activities against four human pathogenic microbes and five fouling bacterial strains. The results indicated that 3,7-dihydroxy-1,9-dimethyldibenzofuran (14) displayed obvious inhibitory activity against Staphylococcus aureus (ATCC 27154) with the MIC value of $13.7 \mu \mathrm{M}$. In addition, the antioxidant assays of the isolated compounds revealed that aspermutarubrol/violaceol-I (15) exhibited significant 1,1-diphenyl-2-picrylhydrazyl (DPPH) radical scavenging activity with the $\mathrm{IC}_{50}$ value of $34.1 \mu \mathrm{M}$, and displayed strong reduction of $\mathrm{Fe}^{3+}$ with the ferric reducing antioxidant power (FRAP) value of $9.0 \mathrm{mM}$ under the concentration of $3.1 \mu \mathrm{g} / \mathrm{mL}$, which were more potent than ascorbic acid.
\end{abstract}

Keywords: Aspergillus versicolor; deep-sea-derived fungus; polyketide; antimicrobial activity; antioxidant activity

\section{Introduction}

Marine-sourced microbes have been deemed as one of the important resources for the discovery of drug lead compounds, with increasing number of diverse new bioactive natural products reported in recent years [1]. A series of remarkable progress have been made in the exploitation of marine microbial resources using various technical strategies, for instance, epigenetic modification [2,3], coculture [4,5], and genome mining [6,7]. The genus Aspergillus was widely distributed in marine environment and marine-derived Aspergillus species was home to a crucial reservoir for producing new bioactive chemical molecules to promote the development of marine drugs [8,9]. So far, plenty 
of novel and active secondary metabolites have been reported from Aspergillus, such as anticancer plinabulin (NPI-2358) [10], $\alpha$-glucosidase inhibitor aspergillusol A [11], and antiviral ochraceopone A and isoasteltoxin [12]. Inspiringly, plinabulin (NPI-2358) was an inhibitor of tubulin polymerization in third phase of clinical study to treat metastatic advanced nonsmall cell lung cancer (NSCLC) [13]. It was noteworthy that the studies of microbial secondary metabolites from extreme marine environments like deep sea have been gradually brought to the forefront in recent decades [14-16]. More and more new bioactive natural products have been discovered from the deep-sea derived Aspergillus, e.g., antifungal versicoloids A and B [17], cytotoxic penicillenols A1 and B1 [18], and anti-inflammatory cyclopenin [19].

As a part of our continuous research for marine bioactive natural products, a variety of bioactive compounds have been obtained from marine-derived Aspergillus genus [20], such as antibacterial (-)-sydonic acid [21], anti-RSV 22-O-(N-Me-L-valyl)-21-epi-aflaquinolone B [22], and antituberculous asperversiamides A-C [23]. Recently, a deep-sea-derived fungus Aspergillus versicolor SH0105 isolated from a Mariana Trench sediment sample $(-5455 \mathrm{~m})$ attracted our attention owing to its EtOAc extract of the fungal culture exhibiting antibacterial activity. The further chemical investigation on the EtOAc extract led to the isolation of four new polyketides (1-2 and 7-8), along with 11 known compounds (3-6 and 9-15) (Figure 1). Herein, we report the isolation, structure elucidation, and biological activities of these compounds.

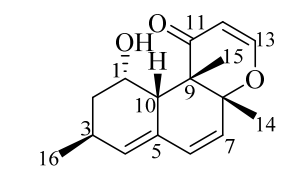

1
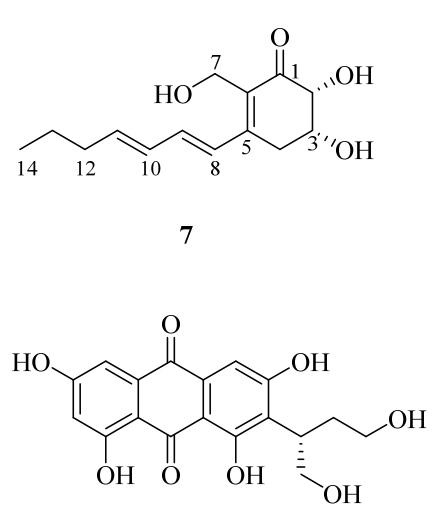

11

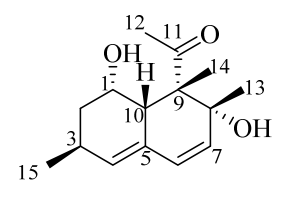

2

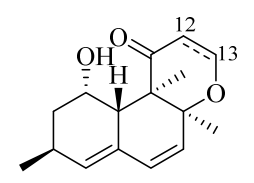

3

$4 \Delta^{12,13}$

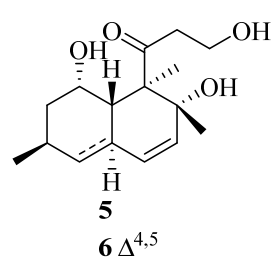

(c)

10

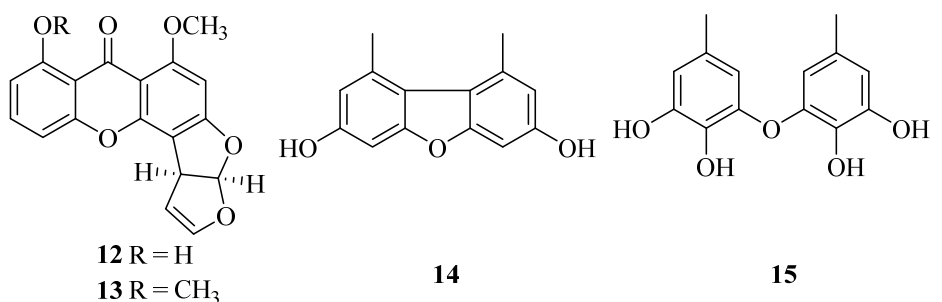

Figure 1. The structures of isolated compounds 1-15.

\section{Results and Discussion}

Isoversiol $\mathrm{F}(\mathbf{1})$ was obtained as a yellowish oil with a molecular formula of $\mathrm{C}_{16} \mathrm{H}_{20} \mathrm{O}_{3}$ on the basis of the HRESIMS at $m / z 261.1492[\mathrm{M}+\mathrm{H}]^{+}$(calcd for 261.1485) (Figure S9), displaying the same molecular formula with the coisolated 12,13-dedihydroversiol (4), which was first isolated from the marine-derived Aspergillus sp. SCS-KFD66 [24]. The ${ }^{1} \mathrm{H}$ NMR, ${ }^{13} \mathrm{C}$ NMR, and HSQC spectra of 1 (Table 1 and Figures S2-S4) revealed the presence of one carbonyl $\left(\delta_{C} 200.2\right)$, one olefinic quaternary carbon $\left(\delta_{\mathrm{C}} 130.3\right)$, five olefinic methine, two sp ${ }^{3}$ quaternary carbons (with one oxygenated $\left(\delta_{\mathrm{C}} 86.2\right)$ ), one methylene $\left(\delta_{\mathrm{C}} 38.8, \delta_{\mathrm{H}} 1.30\right.$ and 2.00$)$, three methines (including one oxymethine $\delta_{\mathrm{C}} 67.5, \delta_{\mathrm{H}} 5.20$ ), and three methyls. These structural features were also very similar to those of 4 . The ${ }^{1} \mathrm{H}^{-}{ }^{1} \mathrm{H}$ COSY interactions and the key HMBC correlations from H-4 to C-2, C-6, C-10, and C-16, from H-13 to C-8 and C-11, from $\mathrm{H}_{3}-14$ to $\mathrm{C}-7$ and C-9, and from $\mathrm{H}_{3}-15$ to $\mathrm{C}-8, \mathrm{C}-9, \mathrm{C}-10$, and C-11 in 1 demonstrated 
the same planar structure with 4 (Figure 2 and Figures S5 and S6). The obvious distinctions were the chemical shifts of the oxymethine $\left(\delta_{\mathrm{C}} 67.5\right.$ and $\left.\delta_{\mathrm{H}} 5.20\right)$ and methyl $\left(\delta_{\mathrm{C}} 17.2\right.$ and $\left.\delta_{\mathrm{H}} 1.28\right)$ in 1 replaced the oxymethine $\left(\delta_{\mathrm{C}} 66.8\right.$ and $\left.\delta_{\mathrm{H}} 3.95\right)$ and methyl $\left(\delta_{\mathrm{C}} 13.5\right.$ and $\left.\delta_{\mathrm{H}} 1.17\right)$ in 4 , respectively, which manifested that compound 1 should be a diastereoisomer of 4 .

Table 1. The ${ }^{1} \mathrm{H}$ and ${ }^{13} \mathrm{C}$ NMR data of $\mathbf{1}-2$ and 7.

\begin{tabular}{|c|c|c|c|c|c|c|}
\hline \multirow{2}{*}{ No. } & \multicolumn{2}{|c|}{$1^{a}$} & \multicolumn{2}{|r|}{$2^{b}$} & \multicolumn{2}{|r|}{$7^{b}$} \\
\hline & $\delta_{\mathrm{C}}$, Type & $\delta_{\mathrm{H}}(J$ in $\mathrm{Hz})$ & $\delta_{C}$, type & $\delta_{\mathrm{H}}(J$ in $\mathrm{Hz})$ & $\delta_{\mathrm{C}}$, Type & $\delta_{\mathrm{H}}(J$ in $\mathrm{Hz})$ \\
\hline 1 & $67.5, \mathrm{CH}$ & $5.20, \mathrm{~m}$ & $67.3, \mathrm{CH}$ & $4.22, \mathrm{~m}$ & $199.6, \mathrm{C}$ & \\
\hline 2 & $38.8, \mathrm{CH}_{2}$ & $\begin{array}{c}2.00, \mathrm{~m} ; 1.30 \\
\mathrm{~m}\end{array}$ & $40.8, \mathrm{CH}_{2}$ & $1.85, \mathrm{~m} ; 1.22, \mathrm{~m}$ & $76.8, \mathrm{CH}$ & $4.31, \mathrm{~d}(3.0)$ \\
\hline 3 & $25.9, \mathrm{CH}$ & $2.56, \mathrm{~m}$ & $26.9, \mathrm{CH}$ & $2.53, \mathrm{~m}$ & $70.9, \mathrm{CH}$ & $4.41, \mathrm{~m}$ \\
\hline 4 & 136.6, $\mathrm{CH}$ & 5.71 , brs & $134.9, \mathrm{CH}$ & 5.58, brs & $33.8, \mathrm{CH}_{2}$ & $\begin{array}{c}\text { 3.01, dd }(18.2,3.5) 2.90 \\
\text { dd }(18.2,3.5)\end{array}$ \\
\hline 5 & $130.3, \mathrm{C}$ & & $132.7, \mathrm{C}$ & & 151.0, C & \\
\hline 6 & $130.5, \mathrm{CH}$ & $6.00, \mathrm{~d}(9.8)$ & 129.6, CH & $5.94, \mathrm{~d}(9.8)$ & $132.5, \mathrm{C}$ & \\
\hline 7 & 127.6, $\mathrm{CH}$ & $5.64, \mathrm{~d}(9.8)$ & 134.1, $\mathrm{CH}$ & $5.35, \mathrm{~d}(9.8)$ & $54.5, \mathrm{CH}_{2}$ & $\begin{array}{c}4.40, \mathrm{~d}(11.6) 4.58, \mathrm{~d} \\
(11.6)\end{array}$ \\
\hline 8 & $86.2, \mathrm{C}$ & & $75.2, \mathrm{C}$ & & $128.4, \mathrm{CH}$ & $6.88, \mathrm{~m}$ \\
\hline 9 & $49.4, \mathrm{C}$ & & $58.9, \mathrm{C}$ & & 139.3, $\mathrm{CH}$ & $6.87, \mathrm{~m}$ \\
\hline 10 & $41.9, \mathrm{CH}$ & $2.65, \mathrm{q}(3.3)$ & $43.3, \mathrm{CH}$ & $2.88, \mathrm{q}(3.3)$ & $132.3, \mathrm{CH}$ & $6.33, \mathrm{ddq}(15.1,8.4,1.4)$ \\
\hline 11 & $200.2, C$ & & $216.3, \mathrm{C}$ & & $142.3, \mathrm{CH}$ & $6.11, \mathrm{dt}(15.1,7.2)$ \\
\hline 12 & $106.5, \mathrm{CH}$ & $5.31, \mathrm{~d}(5.9)$ & $30.8, \mathrm{CH}_{3}$ & $2.28, \mathrm{~s}$ & $36.1, \mathrm{CH}_{2}$ & $2.19, \mathrm{dq}(7.2,1.4)$ \\
\hline 13 & $158.4, \mathrm{CH}$ & $7.05, \mathrm{~d}(5.9)$ & $26.5, \mathrm{CH}_{3}$ & $1.12, \mathrm{~s}$ & 23.3, $\mathrm{CH}_{2}$ & 1.50, qt $(7.4,1.4)$ \\
\hline 14 & 21.0, $\mathrm{CH}_{3}$ & $1.47, \mathrm{~s}$ & $15.2, \mathrm{CH}_{3}$ & $1.44, \mathrm{~s}$ & $14.0, \mathrm{CH}_{3}$ & $0.96, \mathrm{t}(7.4)$ \\
\hline 15 & $17.2, \mathrm{CH}_{3}$ & $1.28, \mathrm{~s}$ & $21.6, \mathrm{CH}_{3}$ & $1.02, \mathrm{~d}(7.1)$ & & \\
\hline 16 & $21.2, \mathrm{CH}_{3}$ & $1.04, \mathrm{~d}(7.1)$ & & & & \\
\hline
\end{tabular}

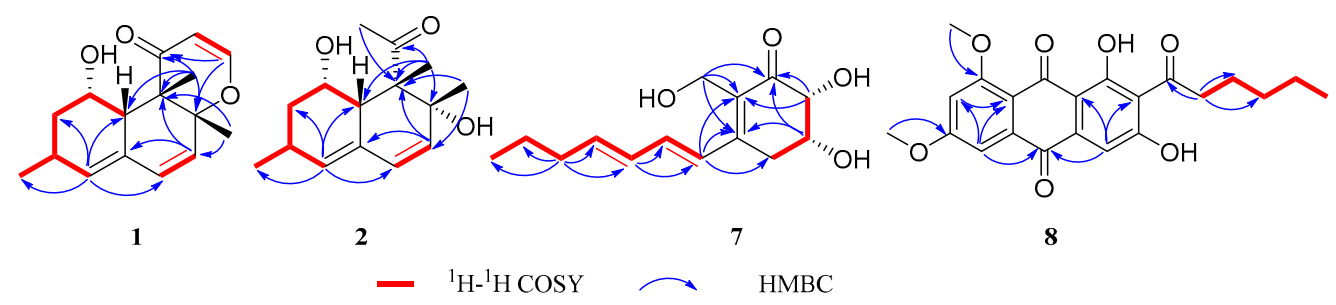

Figure 2. The key ${ }^{1} \mathrm{H}_{-}{ }^{1} \mathrm{H}$ COSY and $\mathrm{HMBC}$ correlations of $\mathbf{1 - 2}$ and 7-8.

The relative configuration of 1 was determined by coupling constants, 1D NOE and 2D NOESY spectra. The small coupling constant of $J_{\mathrm{H}-1, \mathrm{H}-10}=3.3 \mathrm{~Hz}$ reflected the syn-relationship of $\mathrm{H}-1$ and $\mathrm{H}-10$. In the NOE spectrum, the irradiation of $\mathrm{H}_{3}-15\left(\delta_{\mathrm{H}} 1.28\right)$ led to the signal increase of $\mathrm{H}-1\left(\delta_{\mathrm{H}}\right.$ 5.20) and $\mathrm{H}_{3}-16\left(\delta_{\mathrm{H}} 1.04\right)$, suggesting that $\mathrm{H}_{3}-15, \mathrm{H}_{3}-16$, and $\mathrm{H}-1$ should be positioned at the same planar (Figure 3 and Figure S8). Besides, in the NOESY spectrum, the correlation was also observed between $\mathrm{H}-10$ and $\mathrm{H}_{3}-14$ indicating the same face of these protons (Figure 3 and Figure S7). Thus, the relative configuration of 1 was assumed as $1 S^{*}, 3 S^{*}, 8 R^{*}, 9 S^{*}, 10 S^{*}$. The Mosher method was applied to determine the absolute configuration of $\mathbf{1}$, however, it failed. Fortunately, the absolute configuration of 1 was resolved by ECD calculations. Its experimental ECD spectrum agreed with that of calculated $1 S, 3 S, 8 R, 9 S, 10 S-\mathbf{1}$, which exhibited negative Cotton effect at around $230 \mathrm{~nm}$ and positive Cotton effect at around $260 \mathrm{~nm}$ (Figure 4 and Figure S32). Therefore, the absolute configuration of 1 was assigned as $1 S, 3 S, 8 R, 9 S, 10 S$. Compound 1 was a derivative of versiol [25], therefore, we named it as isoversiol $\mathrm{F}$, which followed the reported isoversiols A-E [26]. 


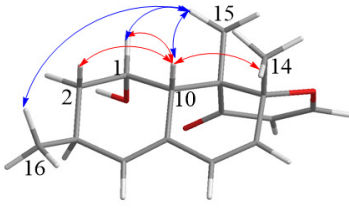

1

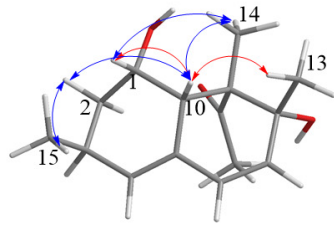

2

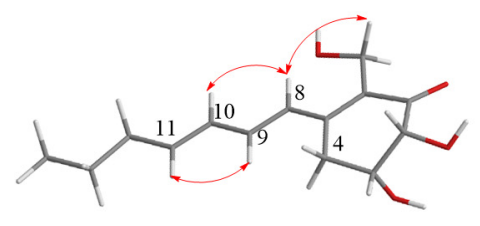

7

Figure 3. The NOE (blue) and NOESY (red) correlations of 1-2 and 7.

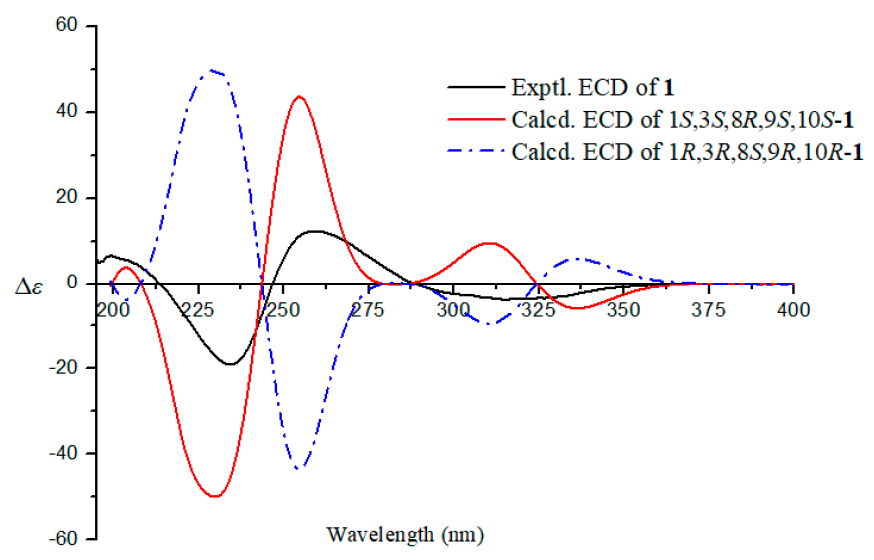

Figure 4. The experimental and calculated ECD spectra of $\mathbf{1}$.

Decumbenone D (2) was also obtained as a yellowish oil and assigned the molecular formula $\mathrm{C}_{15} \mathrm{H}_{22} \mathrm{O}_{3}$ by HRESIMS at $\mathrm{m} / \mathrm{z} 233.1543\left[\mathrm{M}-\mathrm{H}_{2} \mathrm{O}+\mathrm{H}\right]^{+}$(calcd for 233.1536) (Figure S18), with five degrees of unsaturation. The NMR data of 2 (Table 1 and Figures S10-S12) indicated the presence of one ketone carbonyl $\left(\delta_{C}\right.$ 216.3), four olefinic signals (one quaternary), two sp ${ }^{3}$ quaternary carbons (with one oxygenated), three methines (including one oxymethine $\left.\delta_{\mathrm{C}} 67.3, \delta_{\mathrm{H}} 4.22\right)$, one methylene $\left(\delta_{\mathrm{C}}\right.$ $40.8, \delta_{\mathrm{H}} 1.85$ and 1.22), and four methyl groups. These spectroscopic features suggested the presence of a similar skeleton with those of coisolated decumbenone A (6), which was first discovered from the fungus Penicillium decumbens [27]. The distinct differences were the existence of an additional methyl group $\left(\delta_{\mathrm{C}} 30.8\right.$ and $\left.\delta_{\mathrm{H}} 2.28\right)$ in 2 , and the absence of two methylenes (including one oxygenated) of the side chain in 6 , indicating an acetyl group $\left[\mathrm{CH}_{3} \mathrm{CO}-\right]$ of the side chain at $\mathrm{C}-9$ in 2 replaced the 3-hydroxypropionyl group [ $\left.\mathrm{HOCH}_{2} \mathrm{CH}_{2} \mathrm{CO}-\right]$ in 6 , which was verified by the $\mathrm{HMBC}$ correlations from $\mathrm{H}-12$ to $\mathrm{C}-1$ and $\mathrm{C}-9$ (Figure 2 and Figure S14).

The relative configuration of 2 was also determined by coupling constants, $1 \mathrm{D}$ NOE, and 2D NOESY spectra. The small coupling constant of $J_{\mathrm{H}-1, \mathrm{H}-10}=3.3 \mathrm{~Hz}$ demonstrated the same side of $\mathrm{H}-1$ and $\mathrm{H}-10$. In the 1D NOE experiment measured in $\mathrm{CDCl}_{3}$ (Figure 3 and Figure S17), the irradiation of $\mathrm{H}_{3}-14\left(\delta_{\mathrm{H}} 1.46\right)$ enhanced the signal of $\mathrm{H}-10\left(\delta_{\mathrm{H}} 2.98\right)$, and the irradiation of $\mathrm{H}-10$ and $\mathrm{H}_{3}-15\left(\delta_{\mathrm{H}}\right.$ 1.05) simultaneously resulted the enhancement of $\mathrm{H}-2 \mathrm{~b}\left(\delta_{\mathrm{H}} 1.32\right)$, implying that $\mathrm{H}_{3}-14, \mathrm{H}_{3}-15$, and $\mathrm{H}-10$ should be placed at the same face (Figure 3). In addition, the NOESY cross-peaks between H-10 and $\mathrm{H}_{3}-13$ indicated that these protons also should be coplanar (Figure 3 and Figure S15). Herein, the relative configuration of 2 was deduced as $1 S^{*}, 3 S^{*}, 8 R^{*}, 9 S^{*}, 10 S^{*}$. The calculated ECD spectrum of $1 S, 3 S, 8 R, 9 S, 10 S-2$ matched the experimental carve of 2 (Figure 5 and Figure S33). Therefore, the absolute configuration of $\mathbf{2}$ was assumed as $1 S, 3 S, 8 R, 9 S, 10 S$. It was worth mentioning that only the relative stereochemistry of the known compound $\mathbf{6}$ was assumed by Fujii et al. [27]. Herein, we firstly determined the absolute configuration of 6 as $1 S, 3 S, 8 R, 9 R, 10 S$ by comparing the experimental and calculated ECD spectra (Figure 5 and Figure S35). 

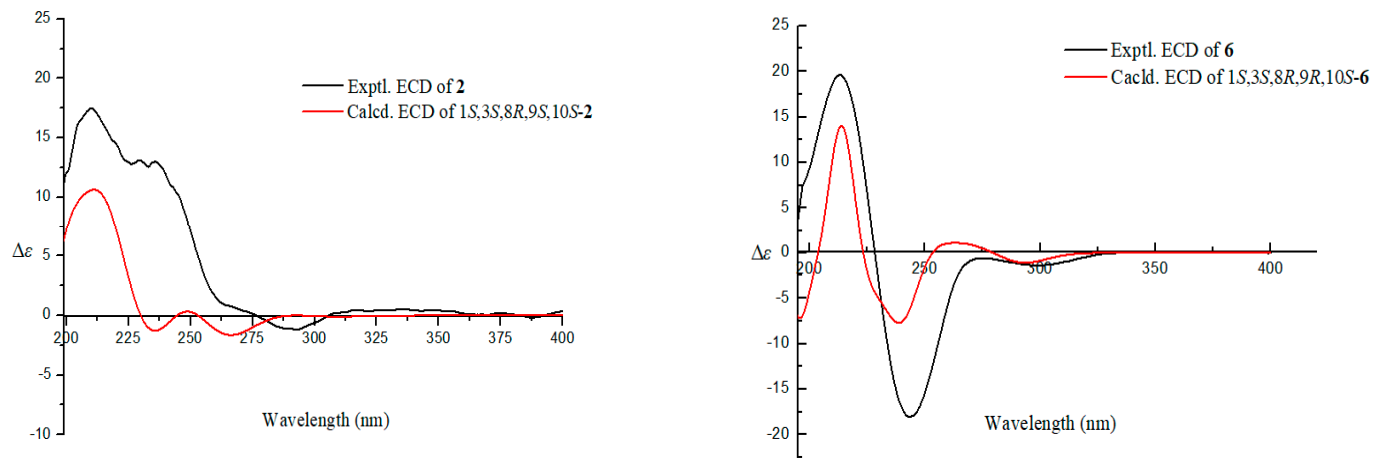

Figure 5. The experimental and calculated ECD spectra of 2 and $\mathbf{6 .}$

Palitantin B (7) was isolated as a yellow solid. Its molecular formula was suggested to be $\mathrm{C}_{14} \mathrm{H}_{20} \mathrm{O}_{4}$ according to its HRESIMS at $m / z 253.1442\left[\mathrm{M}+\mathrm{H}^{+}\right.$(calcd for 253.1434) (Figure S25), with five degrees of unsaturation. The ${ }^{1} \mathrm{H}$ NMR, ${ }^{13} \mathrm{C}$ NMR data of 7 (Table 1 and Figures S19 and S20) displayed the presence of one carbonyl group, six olefinic carbons, two oxymethines, four methylenes, and one methyl group. In the ${ }^{1} \mathrm{H}-{ }^{1} \mathrm{H}$ COSY spectrum, the cross-peaks of $\mathrm{H}-2 / \mathrm{H}-3 / \mathrm{H}-4$ and correlations between $\mathrm{H}-8$ to $\mathrm{H}-14$ demonstrated a residue of $\left[-\mathrm{OCHCH}(\mathrm{O}) \mathrm{CH}_{2}-\right]$ and an aliphatic spin system $\mathrm{C}-8$ to $\mathrm{C}-14$, respectively, which was also verified by the corresponding $\mathrm{HMBC}$ correlations (Figure 2 and Figures S22 and S23). The observed HMBC correlations from H-8 to C-4, C-5, and C-6 and from H-7 to C-1, C-5, and C-6 suggested the aliphatic chain should be located at C-5 and the hydroxymethyl linked at C-6 (Figure 2). Because of the demand of five degrees of unsaturation, an additional ring should be proposed, which was confirmed by the HMBC correlations from $\mathrm{H}-3$ to $\mathrm{C}-1$ and $\mathrm{C}-5$, and $\mathrm{H}-2$ to C-1 and C-6 (Figure 2). Hence, the planar structure of 7 was determined, which was similar with the known palitantin isolated from a plant endophytic A. fumigatiaffinis [28], except that the saturated bond at C-5/C-6 in palitantin was replaced by a double bond in 7 .

The relative configuration of 7 was determined by coupling constants and NOESY correlations. The coupling constant of $J_{\mathrm{H}-2, \mathrm{H}-3}=3.0 \mathrm{~Hz}$ suggested the syn-relationship of $\mathrm{H}-2$ and $\mathrm{H}-3$. The $E$-configuration of the two double bonds was elucidated by the large coupling constant $J_{\mathrm{H}-10, \mathrm{H}-11}=$ $15.1 \mathrm{~Hz}$ and the NOESY correlations of H-9/H-11 and H-8/H-10 (Figure 3 and Figure S24). The absolute configuration of $\mathbf{7}$ was investigated by quantum chemical TDDFT calculations of its ECD spectrum. The experimental ECD spectrum was consistent with the calculated one of 2R,3R-7 (Figure 6 and Figure S34), suggesting the absolute configuration of 7 as $2 R, 3 R$.

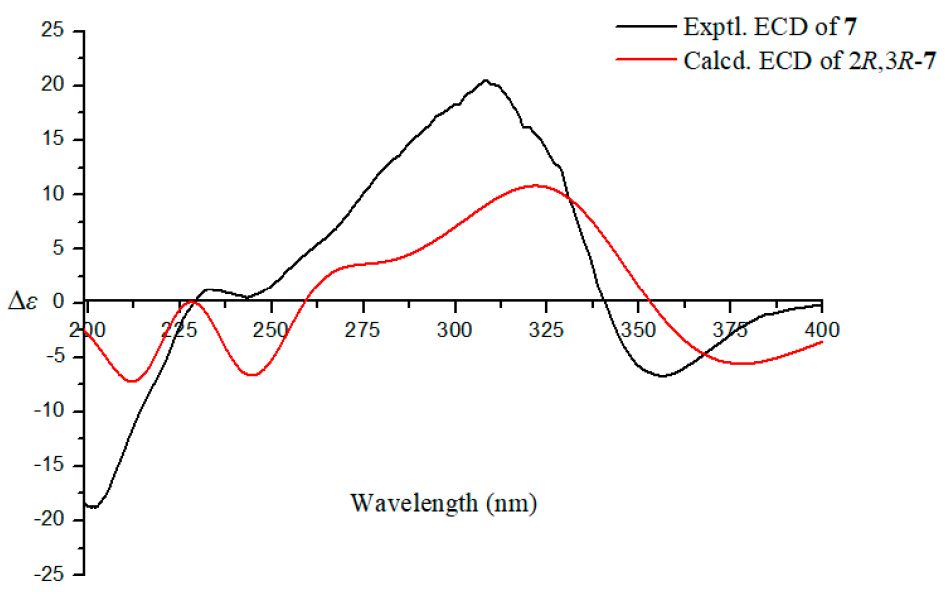

Figure 6. The experimental and calculated ECD spectra of 7.

1,3-Di-O-methyl-norsolorinic acid (8) was isolated as a red powder and assigned the molecular formula as $\mathrm{C}_{22} \mathrm{H}_{22} \mathrm{O}_{7}$ based on its HRESIMS data (Figure S31), including 12 degrees of unsaturation. 
The ${ }^{1} \mathrm{H}$ NMR spectrum (Table 2 and Figure S26) displayed one active hydrogen signal $\left(\delta_{\mathrm{C}} 13.9\right)$, three aromatic protons $\left(\delta_{\mathrm{C}} 6.99(\mathrm{~d}, J=2.5 \mathrm{~Hz}), 7.08(\mathrm{~s}), 7.24(\mathrm{~d}, J=2.5 \mathrm{~Hz})\right)$, two oxymethyl groups, four methylenes, and one methyl. The ${ }^{13} \mathrm{C}$ NMR spectrum (Table 2 and Figure S27) showed the presence of 3 carbonyl groups and 12 aromatic carbons. These spectroscopic features were analogous to those of coisolated norsolorinic acid (9), which was obtained from the fungus Emericella navahoensis [29], except for two additional oxymethyl groups in 8 . The HMBC correlations from these two oxymethyl groups to $C-1$ and $C-3$ revealed that they were attached to $C-1$ and C-3, respectively (Figure 2 and Figure S30). Therefore, the structure of 8 was determined.

Table 2. The ${ }^{1} \mathrm{H}$ and ${ }^{13} \mathrm{C}$ NMR data of 8 in DMSO- $d_{6}$.

\begin{tabular}{cccccc}
\hline No. & $\delta_{\mathrm{C}}$, Type & $\delta_{\mathbf{H}}(\boldsymbol{J}$ in Hz) & No. & $\delta_{\mathrm{C}}$, Type & $\delta_{\mathbf{H}}(\boldsymbol{J}$ in Hz $)$ \\
\hline 1 & $163.1, \mathrm{C}$ & & 13 & $183.5, \mathrm{C}$ & \\
2 & $104.6, \mathrm{CH}$ & $6.99, \mathrm{~d}(2.5)$ & 14 & $113.8, \mathrm{C}$ & \\
3 & $164.9, \mathrm{C}$ & & 15 & $203.2, \mathrm{C}$ & \\
4 & $104.9, \mathrm{CH}$ & $7.24, \mathrm{~d}(2.5)$ & 16 & $43.7, \mathrm{CH}_{2}$ & $2.74, \mathrm{t}(7.3)$ \\
5 & $133.7, \mathrm{C}$ & & 17 & $22.6, \mathrm{CH}_{2}$ & $1.54, \mathrm{dd}(8.5$, \\
6 & $181.8, \mathrm{C}$ & & 18 & $30.7, \mathrm{CH}_{2}$ & $1.25, \mathrm{~m}$ \\
7 & $136.4, \mathrm{C}$ & & 19 & $21.9, \mathrm{CH}_{2}$ & $1.25, \mathrm{~m}$ \\
8 & $106.6, \mathrm{CH}$ & $7.08, \mathrm{~s}$ & 20 & $13.8, \mathrm{CH}_{3}$ & $0.83, \mathrm{t}(7.0)$ \\
9 & $163.0, \mathrm{C}$ & & $1-\mathrm{OCH}_{3}$ & $56.6, \mathrm{CH}_{3}$ & $3.91, \mathrm{~s}$ \\
10 & $121.6, \mathrm{C}$ & & $3-\mathrm{OCH}_{3}$ & $56.2, \mathrm{CH}_{3}$ & $3.99, \mathrm{~s}$ \\
11 & $161.3, \mathrm{C}$ & & $11-\mathrm{OH}$ & & $13.9, \mathrm{~s}$ \\
12 & $109.1, \mathrm{C}$ & & & & \\
\hline
\end{tabular}

The structures of all known compounds, versiol (3) [25], 12,13-dedihydroversiol (4) [24], decumbenones B (5) and A (6) [27], norsolorinic acid (9) [29], 6,8-di-O-methylaverufin (10) [30], versiconol (11) [31], sterigmatocystin (12) [32], O-methylsterigmatocystin (13) [33], 3,7-dihydroxy-1,9dimethyldibenzofuran (14) [34], aspermutarubrol/violaceol-I (15) [35,36], were elucidated by NMR, MS data and comparing with those of reported literature.

Antimicrobial resistance phenomenon is still a global issue, which is threatening the human's life $[37,38]$, indicating that it is very urgent to discover new antimicrobial molecules or mechanisms. In this study, all the isolated compounds 1-15 were evaluated for their antimicrobial activities against four human pathogenic microbes and five fouling bacterial strains. The results suggested that compound 14 displayed strong inhibitory activity against Staphylococcus aureus (ATCC 27154) with the MIC value of $13.7 \mu \mathrm{M}$, which was comparable to the positive control ciprofloxacin (MIC $=9.4 \mu \mathrm{M}$ ), and presented moderate inhibitory activity against Aeromonas salmonicida (ATCC 7965D) with the same MIC value of $13.7 \mu \mathrm{M}$ (sea nine 211, MIC $=1.4 \mu \mathrm{M}$; Table S1). In addition, the antioxidant assays of the isolated compounds were carried out by DPPH radicals scavenging and FRAP models. The results revealed that 15 exhibited significant DPPH radical scavenging activity with the $\mathrm{IC}_{50}$ value of $34.1 \mu \mathrm{M}$ and displayed strong reduction of $\mathrm{Fe}^{3+}$ with the FRAP value of $9.0 \mathrm{mM}$ under the concentration of $3.1 \mu \mathrm{g} / \mathrm{mL}$; thus, $\mathbf{1 5}$ was more potent than the positive control ascorbic acid (DPPH, $\mathrm{IC}_{50}=115.1 \mu \mathrm{M}$; FRAP $=5.6 \mathrm{mM}$ under $3.1 \mu \mathrm{g} / \mathrm{mL}$; Table S2). However, the radical scavenging effects of 1-14 were less than $50 \%$ under the concentration of $50 \mu \mathrm{g} / \mathrm{mL}$.

\section{Materials and Methods}

\subsection{General Experimental Procedures}

The Optical rotations were measured on a JASCO P-1020 digital polarimeter (Jasco Corp., Tokyo, Japan). UV spectra were recorded by a Milton Roy UV-VIS spectrophotometer (Hitachi, Tokyo, Japan). IR spectra were performed on a Nicolet-Nexus-470 spectrometer using $\mathrm{KBr}$ pellets (Thermo Electron, Waltham, MA, USA). NMR spectra were tested by a JEOL JEMECP NMR spectrometer $(600 \mathrm{MHz}$ 
for ${ }^{1} \mathrm{H}$ NMR, $150 \mathrm{MHz}$ for ${ }^{13} \mathrm{C}$ NMR and $500 \mathrm{MHz}$ for NOE spectra, JEOL, Tokyo, Japan) using tetramethylsilane (TMS) as an internal standard. ESIMS spectra were measured on a Micromass Q-TOF spectrometer (Waters Corp., Manchester, UK). ECD spectra were obtained on a JASCO J-815 circular dichroism spectrometer (JASCO Electric Co., Ltd., Tokyo, Japan). In the biological assay, the optical densities (OD) were acquired by a multimode reader Spark 10M (Tecan, Männedorf, Switzerland). Semipreparative HPLC was performed on a Hitachi L-2000 HPLC system coupled with a Hitachi L-2455 photodiode array detector and a Kromasil $\mathrm{C}_{18}$ semipreparative HPLC column $(250 \mathrm{~mm} \times$ $10 \mathrm{~mm}, 5 \mu \mathrm{m}$ ). Silica gel (Qingdao Haiyang Chemical Group Co., Qingdao, China) and Sephadex LH-20 (Amersham Biosciences Inc., Piscataway, NJ, USA) were used for column chromatography (CC). Precoated silica gel GF254 plates (Yantai Zifu Chemical Group Co., Yantai, China) were used for thin layer chromatography (TLC).

\subsection{Fungal Material}

The fungal strain A. versicolor SH0105 was isolated from a deep-sea sediment sample collected at a depth of $5455 \mathrm{~m}$ from the Mariana Trench. The strain was deposited in the Key Laboratory of Marine Drugs, the Ministry of Education of China, School of Medicine and Pharmacy, Ocean University of China, Qingdao, China. The fungal strain was identified as A. versicolor according to its morphological features, amplification and sequencing of the DNA sequences of the ITS region, and construction of phylogenetic tree by MEGA 7.0 (Temple University, Philadelphia, PA, USA; Figure S1). The sequence data was submitted to NCBI with the GeneBank accession number MT620963.

\subsection{Fermentation, Extraction, and Isolation}

The fungal strain was cultured on rice solid medium $(100 \times 1000 \mathrm{~mL}$ Erlenmeyer flasks, each containing $80 \mathrm{~g}$ of rice and $80 \mathrm{~mL}$ of sea water) for 60 days at $25^{\circ} \mathrm{C}$. The fermented rice substrate was extracted three times with ethyl acetate (EtOAc) and concentrated under the vacuum evaporation to yield an organic extract $(85 \mathrm{~g})$. Then, the extract was performed on the silica gel vacuum liquid chromatography (VLC) eluting by a gradient of petroleum ether (PE)—EtOAc (100\%, 90\%, 70\%, 50\%, and $0 \% \mathrm{PE}$ ) and 10\% EtOAc-MeOH to give six fractions (Fr.1-Fr.6). Fr.3 was subjected to the octadecyl silane (ODS) column with $\mathrm{MeOH}-\mathrm{H}_{2} \mathrm{O}(15-100 \%)$ to afford four subfractions (Fr.3A-Fr.3D). Fr.3A was separated by Sephadex LH-20 column chromatography (CC) eluting with $\mathrm{MeOH}$ and then purified by semipreparative HPLC (75\% MeOH- $\mathrm{H}_{2} \mathrm{O}$ ) to obtain 1 (2 mg), 2 (4 mg), 3 (18 mg), and 4 (4 mg). Fr.3B was repeatedly isolated by silica gel CC eluting with PE-EtOAc to produce $\mathbf{1 2}(10 \mathrm{mg})$ and $\mathbf{1 3}(8 \mathrm{mg})$. Fr.3C was subjected to Sephadex LH-20 CC and then performed on HPLC $\left(60 \% \mathrm{MeOH}-\mathrm{H}_{2} \mathrm{O}\right)$ to yield $14(5 \mathrm{mg})$ and $15(38 \mathrm{mg})$. Fr.3D was chromatographed on silica gel CC and recrystallized to give 8 $(6 \mathrm{mg})$ and $9(12 \mathrm{mg})$. Fr.4 was also fractionated on ODS column with $\mathrm{MeOH}-\mathrm{H}_{2} \mathrm{O}(15-100 \%)$ to obtain three subfractions (Fr.4A-Fr.4C). Fr.4A was subjected to Sephadex $\mathrm{LH}-20 \mathrm{CC}\left(50 \% \mathrm{CH}_{2} \mathrm{Cl}_{2}-\mathrm{MeOH}\right)$ to obtain two subfractions (Fr.4A1-Fr.4A2). Fr.4A1 was purified on HPLC $\left(45 \% \mathrm{MeOH}-\mathrm{H}_{2} \mathrm{O}\right)$ to yield 7 (14 mg). Fr.4A2 was reseparated by silica gel CC and HPLC $\left(60 \% \mathrm{MeOH}-\mathrm{H}_{2} \mathrm{O}\right)$ to provide $5(65 \mathrm{mg})$ and $6(26 \mathrm{mg})$. Fr.4B was isolated on silica gel CC and further eluted with Sephadex LH-20 CC (50\% $\left.\mathrm{CH}_{2} \mathrm{Cl}_{2}-\mathrm{MeOH}\right)$ to afford $\mathbf{9}(6 \mathrm{mg})$ and $\mathbf{1 1}(9 \mathrm{mg})$.

Isoversiol F (1): yellowish oil; $[\alpha]_{\mathrm{D}}^{20}-11(c 0.1, \mathrm{MeOH}) ; \mathrm{UV}(\mathrm{MeOH}) \lambda_{\max }(\log \varepsilon) 236(1.48) \mathrm{nm} ; \mathrm{IR}$ $(\mathrm{KBr}) v_{\max } 3734,2360,1699,1539,1033 \mathrm{~cm}^{-1} ;{ }^{1} \mathrm{H}$ and ${ }^{13} \mathrm{C}$ NMR see Table 1 ; HRESIMS $\mathrm{m} / z$ 261.1492 [M $+\mathrm{H}]^{+}$(calcd for $\mathrm{C}_{16} \mathrm{H}_{21} \mathrm{O}_{3}, 261.1485$ ).

Decumbenone D (2): yellowish oil; $[\alpha]_{\mathrm{D}}^{20}+70.8$ (c 0.1, MeOH); UV (MeOH) $\lambda_{\max }(\log \varepsilon) 283$ (1.93) $\mathrm{nm}$; IR (KBr) $v_{\max } 3444,2958,2360,1687,1380,1113 \mathrm{~cm}^{-1} ;{ }^{1} \mathrm{H}$ and ${ }^{13} \mathrm{C}$ NMR see Table 1 ; HRESIMS $\mathrm{m} / \mathrm{z}$ 233.1543 $\left[\mathrm{M}+\mathrm{H}_{2} \mathrm{O}+\mathrm{H}\right]^{+}$(calcd for $\mathrm{C}_{15} \mathrm{H}_{21} \mathrm{O}_{2}, 233.1536$ ).

Palitantin B (7): yellow solid; $[\alpha]_{\mathrm{D}}^{20}+53.2($ c $0.1, \mathrm{MeOH}) ; \mathrm{UV}(\mathrm{MeOH}) \lambda_{\max }(\log \varepsilon) 321(2.66) \mathrm{nm}$; IR $(\mathrm{KBr}) v_{\max } 3748,2361,1658,1598,987 \mathrm{~cm}^{-1} ;{ }^{1} \mathrm{H}$ and ${ }^{13} \mathrm{C}$ NMR see Table 1 ; HRESIMS $\mathrm{m} / z 253.1442[\mathrm{M}+$ $\mathrm{H}^{+}$(calcd for $\left.\mathrm{C}_{14} \mathrm{H}_{21} \mathrm{O}_{4}, 253.1434\right) ; 275.1262[\mathrm{M}+\mathrm{Na}]^{+}$(calcd for $\mathrm{C}_{14} \mathrm{H}_{20} \mathrm{O}_{4} \mathrm{Na}, 275.1254$ ). 
1,3-Di-O-methyl-norsolorinic acid (8): red powder; $\mathrm{UV}\left(\mathrm{CHCl}_{3}\right) \lambda_{\max }(\log \varepsilon) 245$ (1.24), 260 (1.05), $340(0.65) \mathrm{nm} ; \mathrm{IR}(\mathrm{KBr}) v_{\max } 3362,2362,1683,1423,1059 \mathrm{~cm}^{-1} ;{ }^{1} \mathrm{H}$ and ${ }^{13} \mathrm{C}$ NMR see Table 2; HRESIMS $m / z$ 397.1282 [M $+\mathrm{H}]^{+}$(calcd for $\mathrm{C}_{22} \mathrm{H}_{21} \mathrm{O}_{7}, 397.1293$ ).

\subsection{ECD Calculations}

The Merck molecular force field (MMFF94S) was used to conformational searches of compounds 1-2 and 6-7 during theoretical ECD calculations. All conformers were optimized twice by the basis set at the B3LYP/6-31G (d) and B3LYP/6-311+G (d) levels using the Gaussian 09 (Gaussian Inc., Wallingford, CT, USA) [39]. The ECD spectrum was calculated by the time-dependent density functional theory (TD-DFT) method at B3LYP/6-311++G (2d, p) level and simulated by Boltzmann distributions in SpecDis 1.62 (University of Würzburg, Würzburg, Germany) [40].

\subsection{Biological Assays}

\subsubsection{Antimicrobial Assay}

The antimicrobial assays were evaluated using a broth microdilution method in 96-well polystyrene microtiter plates Costar 3599 (Corning Inc., New York, NY, USA) according to the standard of Clinical and Laboratory Standards Institute (CLSI) [41]. Three pathogenic bacterial strains, Staphylococcus aureus (ATCC 27154), Escherichia coli (ATCC 25922), and Pseudomonas aeruginosa (ATCC 10145); five fouling bacterial strains, P. fulva (ATCC 31418), Aeromonas salmonicida (ATCC 7965D), Photobacterium angustum (ATCC 33975), Enterobacter cloacae (ATCC 39978), and E. hormaechei (ATCC 700323); and one pathogenic fungal strain Candida albicans (ATCC 76485) were used as the test strains. First, the tested pathogenic bacteria, fouling bacteria, and pathogenic fungus were inoculated in $10 \mathrm{~mL}$ of LB (yeast extract $5 \mathrm{~g} / \mathrm{L}$, peptone $10 \mathrm{~g} / \mathrm{L}, \mathrm{NaCl} 10 \mathrm{~g} / \mathrm{L}$ ), 2216E (Hopebio, Qingdao, China), and YM (Hopebio, Qingdao, China) liquid medium, respectively, and cultivated at $37^{\circ} \mathrm{C}$ for $12 \mathrm{~h}$ to yield the initial microbial liquids. The microbial density was adjusted to 0.5 MacFarland and then diluted 1000 times using the corresponding broth to obtain the tested microbial suspension with an inoculum density of $1 \times 10^{5} \mathrm{cfu} / \mathrm{mL}$. The tested compounds were dissolved in 100\% DMSO to obtain the mother solution with the initial concentration of $1 \mathrm{mg} / \mathrm{mL}$. Following the principle of twofold serial dilution, each well contained $5 \mu \mathrm{L}$ of tested compounds and $195 \mu \mathrm{L}$ of the microbial suspension to obtain the final measured concentration of $25-0.098 \mu \mathrm{g} / \mathrm{mL}$. Finally, the plates were incubated at $37^{\circ} \mathrm{C}$ for $24 \mathrm{~h}$ and the optical density of each well was recorded by microplate reader (Tecan, Männedorf, Switzerland) at $600 \mathrm{~nm}$. MIC represents the minimal inhibitory concentration of compound without visible microbial growth. The antimicrobial assays were performed in triplicate. Broad-spectrum antimicrobial ciprofloxacin and commercial antifouling sea-nine 211 were used as positive controls for pathogenic and fouling microbial strains, respectively. DMSO was used as a negative control.

\subsubsection{Antioxidant Activity}

The DPPH radical scavenging assay and ferric reducing antioxidant power assay (FRAP) were used to evaluate the antioxidant activities of the isolated compounds [42]. The samples and positive control ascorbic acid were dissolved in DMSO with final concentrations of 100, 50, 25, 12.5, and $6.25 \mu \mathrm{g} / \mathrm{mL}$. DPPH was dissolved in anhydrous ethanol $(\mathrm{EtOH})$ with the concentrations of $0.05 \mathrm{mg} / \mathrm{mL}$. Fe ${ }^{3+}$-TPTZ solution consisted of $2 \mathrm{mmol} / \mathrm{L} \mathrm{FeCl}_{3}$ and 2,4,6-Tris(2-pyridyl)-s-triazine (TPTZ), respectively. Tested samples $(100 \mu \mathrm{L})$ were added to $100 \mu \mathrm{L}$ of fresh DPPH or $\mathrm{Fe}^{3+}$-TPTZ solution, then reacted in the dark for $30 \mathrm{~min}$. The optical density (OD) was measured by a multimode reader Spark $10 \mathrm{M}$ (Tecan, Männedorf, Switzerland) at 517 and $593 \mathrm{~nm}$, respectively. The EtOH and DMSO were employed as a blank and negative control, respectively. The $\mathrm{IC}_{50}$ values were calculated on the software of GraphPad Prism 5 (GraphPad Software Inc., San Diego, CA, USA). 


\section{Conclusions}

Deep-sea derived fungi are potential resources to seek for structural novel and diverse biological natural products. In the present study, chemical investigation of the deep-sea-derived fungus A. versicolor SH0105 led to the isolation of four new polyketides (1-2 and 7-8), along with 11 known compounds (3-6 and 9-15), which enriched the diversity of secondary metabolites from the deep-sea-derived Aspergillus. The structures and absolute configurations of new compounds were elucidated by comprehensive spectroscopic data and ECD calculations, and it is the first time to determine the absolute configuration of known decumbenone A (6). In the bioactive assays, compound 14 displayed obvious inhibitory activity against S. aureus (ATCC 27154) and 15 exhibited significant DPPH radical scavenging activity and displayed strong reduction of $\mathrm{Fe}^{3+}$, which were more potent than ascorbic acid, indicating the prospect to discovery of chemical entities with antimicrobial and antioxidant activities from the deep-sea medicinal microbial resources.

Supplementary Materials: The following are available online at http://www.mdpi.com/1660-3397/18/12/636/s1. Figure S1: The neighbor-joining phylogenetic tree of the fungus A. versicolor SH0105: Figure S2 to Figure S31: The HRESIMS and 1D and 2D NMR spectra of new compounds 1-2 and 7-8; Figure S32 to Figure S35: The lowest-energy conformers of compounds 1-2 and 6-7 in ECD calculations; Table S1 and Table S2: The data of antimicrobial and antioxidant activities.

Author Contributions: L.-J.Y. contributed to extraction, isolation, structural elucidation, and manuscript preparation; X.-Y.P. contributed to the fermentation of the fungus; Y.-H.Z. contributed to the ECD calculations; Z.-Q.L. and X.L. contributed to the evaluation of bioactivities of the isolated compounds; Y.-C.G. and C.-L.S. contributed to the critical reading of the manuscript; Z.H. and C.-Y.W. designed the project and manuscript writing. All authors have read and agreed to the published version of the manuscript.

Funding: This work was supported by the Shandong Provincial Natural Science Foundation (Major Basic Research Projects), China (ZR2019ZD18), the Program of Open Studio for Druggability Research of Marine Natural Products, Pilot National Laboratory for Marine Science and Technology (Qingdao, China) Directed by Kai-Xian Chen and Yue-Wei Guo, and the Taishan Scholars Program, China.

Acknowledgments: This paper is dedicated to Youyou Tu, the 2015 Nobel Prize Laureate of Physiology or Medicine on the occasion of her 90th birthday. Lu-Jia Yang is thankful for the Syngenta-OUC-PhD Studentship.

Conflicts of Interest: The authors declare no conflict of interest.

\section{References}

1. Carroll, A.R.; Copp, B.R.; Davis, R.A.; Keyzers, R.A.; Prinsep, M.R. Marine natural products. Nat. Prod. Rep. 2020, 37, 175-223. [CrossRef]

2. Zhang, Z.Z.; He, X.Q.; Wu, G.W.; Liu, C.C.; Lu, C.J.; Gu, Q.Q.; Che, Q.; Zhu, T.J.; Zhang, G.J.; Li, D.H. Aniline-tetramic acids from the deep-sea-derived fungus Cladosporium sphaerospermum L3P3 cultured with the HDAC inhibitor SAHA. J. Nat. Prod. 2018, 81, 1651-1657. [CrossRef]

3. Wu, J.S.; Yao, G.S.; Shi, X.H.; Rehman, S.U.; Xu, Y.; Fu, X.M.; Zhang, X.L.; Liu, Y.; Wang, C.Y. Epigenetic agents trigger the production of bioactive nucleoside derivatives and bisabolane sesquiterpenes from the marine-derived fungus Aspergillus versicolor. Front. Microbiol. 2020, 11, 85. [CrossRef]

4. Yu, M.L.; Li, Y.X.; Banakar, S.P.; Liu, L.; Shao, C.L.; Li, Z.Y.; Wang, C.Y. New metabolites from the co-culture of marine-derived actinomycete Streptomyces rochei MB037 and fungus Rhinocladiella similis 35. Front. Microbiol. 2019, 10, 915. [CrossRef] [PubMed]

5. Peng, X.Y.; Wu, J.T.; Shao, C.L.; Li, Z.Y.; Chen, M.; Wang, C.Y. Co-culture: Stimulate the metabolic potential and explore the molecular diversity of natural products from microorganisms. Mar. Life. Sci. Technol. 2020. [CrossRef]

6. Li, Z.Y.; Zhu, D.Y.; Shen, Y.M. Discovery of novel bioactive natural products driven by genome mining. Drug. Discov. Ther. 2018, 12, 318-328. [CrossRef] [PubMed]

7. Liu, Q.; Liu, Z.Y.; Sun, C.L.; Shao, M.W.; Ma, J.Y.; Wei, X.Y.; Zhang, T.Y.; Li, W.J.; Ju, J.H. Discovery and biosynthesis of atrovimycin, an antitubercular and antifungal cyclodepsipeptide featuring vicinal-dihydroxylated cinnamic acyl chain. Org. Lett. 2019, 21, 2634-2638. [CrossRef] [PubMed]

8. Zhao, C.Y.; Liu, H.S.; Zhu, W.M. New natural products from the marine-derived Aspergillus fungi-A review. Acta Microbiol. Sin. 2016, 56, 331-362. [CrossRef] 
9. Wang, K.W.; Ding, P. New bioactive metabolites from the marine-derived fungi Aspergillus. Mini-Rev. Med. Chem. 2018, 18, 1072-1094. [CrossRef] [PubMed]

10. Nicholson, B.; Lloyd, K.; Miller, B.R.; Palladino, M.A.; Kiso, Y.; Hayashi, Y.; Neuteboom, S.T.C. NPI-2358 is a tubulin-depolymerizing agent: In-vitro evidence for activity as a tumor vascular-disrupting agent. Anti-Cancer Drug. 2006, 17, 25-31. [CrossRef] [PubMed]

11. Ingavat, N.; Dobereiner, J.; Wiyakrutta, S.; Mahidol, C.; Ruchirawat, S.; Kittakoop, P. Aspergillusol A, an $\alpha$-glucosidase inhibitor from the marine-derived fungus Aspergillus aculeatus. J. Nat. Prod. 2009, 72, 2049-2052. [CrossRef] [PubMed]

12. Wang, J.F.; Wei, X.Y.; Qin, X.C.; Tian, X.P.; Li, K.M.; Zhou, X.F.; Yang, X.W.; Wang, F.Z.; Zhang, T.Y.; Tu, Z.C.; et al. Antiviral merosesquiterpenoids produced by the Antarctic fungus Aspergillus ochraceopetaliformis SCSIO 05702. J. Nat. Prod. 2016, 79, 59-65. [CrossRef] [PubMed]

13. Cimino, P.J.; Huang, L.; Du, L.H.; Wu, Y.P.; Bishop, J.; Dalsing-Hernandez, J.; Kotlarczyk, K.; Gonzales, P.; Carew, J.; Nawrocki, S.; et al. Plinabulin, an inhibitor of tubulin polymerization, targets KRAS signaling through disruption of endosomal recycling. Biomed. Rep. 2019, 10, 218-224. [CrossRef] [PubMed]

14. Zhang, X.Y.; Zhang, Y.; Xu, X.Y.; Qi, S.H. Diverse deep-sea fungi from the south China sea and their antimicrobial activity. Curr. Microbiol. 2013, 67, 525-530. [CrossRef] [PubMed]

15. Wang, Y.T.; Xue, Y.R.; Liu, C.H. A brief review of bioactive metabolites derived from deep-sea fungi. Mar. Drugs. 2015, 13, 4594-4616. [CrossRef] [PubMed]

16. Wilson, Z.E.; Brimble, M.A. Molecules derived from the extremes of life: A decade later. Nat. Prod. Rep. 2020. [CrossRef] [PubMed]

17. Wang, J.F.; He, W.J.; Huang, X.L.; Tian, X.P.; Liao, S.R.; Yang, B.; Wang, F.Z.; Zhou, X.J.; Liu, Y.H. Antifungal new oxepine-containing alkaloids and xanthones from the deep-sea-derived fungus Aspergillus versicolor SCSIO 05879. J. Agr. Food. Chem. 2016, 64, 2910-2916. [CrossRef]

18. Wang, J.; Yao, Q.F.; Amin, M.; Nong, X.H.; Zhang, X.Y.; Qi, S.H. Penicillenols from a deep-sea fungus Aspergillus restrictus inhibit Candida albicans biofilm formation and hyphal growth. J. Antibiot. 2017, 70, 763-770. [CrossRef]

19. Wang, L.Y.; Li, M.J.; Lin, Y.Z.; Du, S.W.; Liu, Z.Y.; Ju, J.H.; Suzuki, H.; Sawada, M.; Umezawa, K. Inhibition of cellular inflammatory mediator production and amelioration of learning deficit in flies by deep sea Aspergillus derived cyclopenin. J. Antibiot. 2020, 73, 622-629. [CrossRef]

20. Liu, L.; Zheng, Y.Y.; Shao, C.L.; Wang, C.Y. Metabolites from marine invertebrates and their symbiotic microorganisms: Molecular diversity discovery, mining, and application. Mar. Life. Sci. Technol. 2019, 1, 60-94. [CrossRef]

21. Li, D.; Xu, Y.; Shao, C.L.; Yang, R.Y.; Zheng, C.J.; Chen, Y.Y.; Fu, X.M.; Qian, P.Y.; She, Z.G.; Voogd, N.J.D.; et al. Antibacterial bisabolane-type sesquiterpenoids from the sponge-derived fungus Aspergillus sp. Mar. Drugs. 2012, 10, 234-241. [CrossRef] [PubMed]

22. Chen, M.; Shao, C.L.; Meng, H.; She, Z.G.; Wang, C.Y. Anti-respiratory syncytial virus prenylated dihydroquinolone derivatives from the gorgonian-derived fungus Aspergillus sp. XS-20090B15. J. Nat. Prod. 2014, 77, 2720-2724. [CrossRef] [PubMed]

23. Hou, X.M.; Liang, T.M.; Guo, Z.Y.; Wang, C.Y.; Shao, C.L. Discovery, absolute assignments, and total synthesis of asperversiamides A-C and their potent activity against Mycobacterium marinum. Chem. Commun. 2019, 55, 1104-1107. [CrossRef] [PubMed]

24. An, C.L.; Kong, F.D.; Ma, Q.Y.; Xie, Q.Y.; Yuan, J.Z.; Zhou, L.M.; Dai, H.F.; Yu, Z.F.; Zhao, Y.X. Chemical constituents of the marine-derived fungus Aspergillus sp. SCS-KFD66. Mar. Drugs. 2018, 16, 468. [CrossRef] [PubMed]

25. Fukuyama, K.; Tsukihara, T.; Katsube, Y. Structure of versiol, a new metabolite from Aspergillus versicolor. Tetrahedron Lett. 1976, 3, 189-190. [CrossRef]

26. Cho, N.; Ransom, T.T.; Sigmund, J.; Cichewicz, R.H.; Goetz, M.; Beutler, J.A. Growth inhibition of colon cancer and melanoma cells by versiol derivatives from a Paraconiothyrium species. J. Nat. Prod. 2017, 80, 2037-2044. [CrossRef]

27. Fujii, Y.; Asahara, M.; Ichinoe, M.; Nakajima, H. Fungal melanin inhibitor and related compounds from Penicillium decumbens. Phytochemistry 2002, 60, 703-708. [CrossRef]

28. Ola, A.R.B.; Tawo, B.D.; Belli, H.L.L.; Proksch, P.; Tommy, D.; Hakim, E.H. A new antibacterial polyketide from the endophytic fungi Aspergillus fumigatiaffinis. Nat. Prod. Commun. 2018, 13, 1573-1574. [CrossRef] 
29. Yamazaki, M.; Satoh, Y.; Maebayashi, Y.; Horie, Y. Monoamine oxidase inhibitors from a fungus, Emericella navahoensis. Chem. Pharm. Bull. 1988, 36, 670-675. [CrossRef]

30. Shao, C.L.; Wang, C.Y.; Wei, M.Y.; Li, S.D.; She, Z.G.; Gu, Y.C.; Lin, Y.C. Structural and spectral assignments of six anthraquinone derivatives from the mangrove fungus (ZSUH-36). Magn. Reson. Chem. 2008, 46, 886-889. [CrossRef]

31. Steyn, P.S.; Vleggaar, R.; Wessels, P.L. Structure and carbon-13 nuclear magnetic resonance assignments of versiconal acetate, versiconol acetate, and versiconol, metabolites from cultures of Aspergillus parasiticus treated with dichlorvos. J. Chem. Soc. Perkin Trans. 1979, 1, 451-459. [CrossRef]

32. Lee, Y.M.; Li, H.Y.; Hong, J.; Cho, H.Y.; Bae, K.S.; Kim, M.A.; Kim, D.K.; Jung, J.H. Bioactive metabolites from the sponge-derived fungus Aspergillus versicolor. Arch. Pharm. Res. 2010, 33, 231-235. [CrossRef] [PubMed]

33. Cox, R.H.; Cole, R.J. Carbon-13 nuclear magnetic resonance studies of fungal metabolites, aflatoxins, and sterigmatocystins. J. Org. Chem. 1977, 42, 112-114. [CrossRef] [PubMed]

34. Tanahashia, T.; Takenaka, Y.; Nagakura, N.; Hamada, N. Dibenzofurans from the cultured lichen mycobionts of Ecanora cinereocarnea. Phytochemistry 2001, 8, 1129-1134. [CrossRef]

35. Taniguchi, M.; Kaneda, N.; Shibata, K.; Kamikawa, T. Isolation and biological activity of aspermutarubrol, a self-growth inhibitor from Aspergillus sydowi. Agr. Biol. Chem. 1978, 42, 1629-1630. [CrossRef]

36. Nakamaru, T.; Shiojiri, H.; Kawai, K.; Nozawa, Y.; Maebayashi, Y.; Yamazaki, M. The effects of toxic metabolites violaceol I and II from Emericella violacea on mitochondrial respiration. Mycotoxins. 1984, 19, 30-33. [CrossRef]

37. Chakraborty, M.; Chakraborty, A.; Mukherjee, P. Antibiotic resistance: The global crisis. J. Pharm. Res 2020, 9 , 12-16. [CrossRef]

38. Dugassa, J.; Shukuri, N. Review on antibiotic resistance and its mechanism of development. J. Health Med. Nurs. 2017, 1, 1-17.

39. Frisch, M.J.; Trucks, G.W.; Schlegel, H.B.; Scuseria, G.E.; Robb, M.A.; Cheeseman, J.R.; Scalmani, G.; Barone, V.; Mennucci, B.; Petersson, G.A.; et al. Gaussian 09, Revision D.01; Gaussian Inc.: Wallingford, CT, USA, 2013.

40. Bruhn, T.; Schaumloffel, A.; Hemberger, Y.; Bringmann, G. SpecDis: Quantifying the comparison of calculated and experimental electronic circular dichroism spectra. Chirality 2013, 25, 243-249. [CrossRef]

41. Clinical and Laboratory Standards Institute (CLSI). Performance Standards for Antimicrobial Susceptibility Testing; Twenty-Second Informational Supplement M100-S22; Clinical and Laboratory Standards Institute: Wayne, PA, USA, 2012.

42. Aktumsek, A.; Zengin, G.; Guler, G.O.; Cakmak, Y.S.; Duran, A. Antioxidant potentials and anticholinesterase activities of methanolic andaqueous extracts of three endemic Centaurea L. species. Food. Chem. Toxicol. 2013, 55, 290-296. [CrossRef]

Publisher's Note: MDPI stays neutral with regard to jurisdictional claims in published maps and institutional affiliations.

(C) 2020 by the authors. Licensee MDPI, Basel, Switzerland. This article is an open access article distributed under the terms and conditions of the Creative Commons Attribution (CC BY) license (http://creativecommons.org/licenses/by/4.0/). 